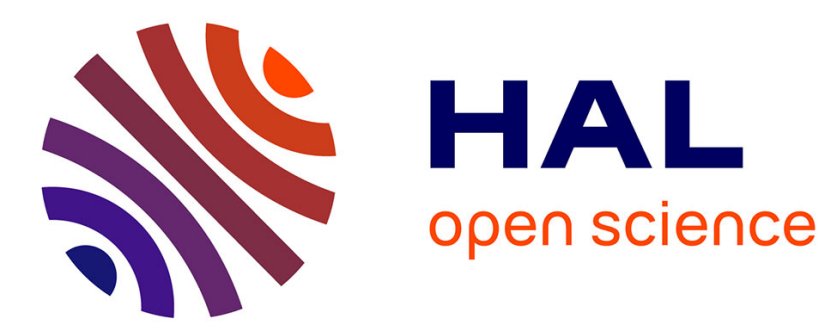

\title{
Carbon in heartwood, sapwood and bark along the stem profile in three Mediterranean Pinus species
}

Herrero de Aza, María Turrión, Pando, Bravo

\section{To cite this version:}

Herrero de Aza, María Turrión, Pando, Bravo. Carbon in heartwood, sapwood and bark along the stem profile in three Mediterranean Pinus species. Annals of Forest Science, 2011, 68 (6), pp.1067-1076. 10.1007/s13595-011-0122-y . hal-00930692

\section{HAL Id: hal-00930692 \\ https://hal.science/hal-00930692}

Submitted on 1 Jan 2011

HAL is a multi-disciplinary open access archive for the deposit and dissemination of scientific research documents, whether they are published or not. The documents may come from teaching and research institutions in France or abroad, or from public or private research centers.
L'archive ouverte pluridisciplinaire HAL, est destinée au dépôt et à la diffusion de documents scientifiques de niveau recherche, publiés ou non, émanant des établissements d'enseignement et de recherche français ou étrangers, des laboratoires publics ou privés. 


\title{
Carbon in heartwood, sapwood and bark along the stem profile in three Mediterranean Pinus species
}

\author{
Celia Herrero de Aza • María Belén Turrión • \\ Valentín Pando • Felipe Bravo
}

Received: 30 October 2010 /Accepted: 1 March 2011 /Published online: 2 September 2011

(C) INRA and Springer Science+Business Media B.V. 2011

\begin{abstract}
- Context Understanding biological processes in forests is necessary to orientate ecosystem management towards potential $\mathrm{C}$ sequestration. To achieve this, information is required about changes in forest biomass $\mathrm{C}$ pools, including the stem components (bark, sapwood and heartwood).

- Aims This study aimed to determine whether there are differences in $\mathrm{C}$ concentration in axial and radial directions within stem biomass in Pinus nigra, Pinus pinaster and Pinus sylvestris.

- Methods Wood samples from a permanent plantation in northern Spain were examined for $\mathrm{C}$ concentration and wood bulk density.

- Results The results showed that C concentration was higher in heartwood than in sapwood in the three species. Pinus spp. sapwood C concentration increased along the stem, while the $\mathrm{C}$ concentration in heartwood tissue showed the opposite behavior. In bark, Pinus pinaster showed a decreasing trend, in contrast to Pinus nigra and Pinus sylvestris, where higher values were found at the base and top of the stem. Finally, wood bulk density decreased in heartwood, sapwood and bark areas when stem height increased. Estimating $\mathrm{C}$ content taking into account different anatomical parts and heights is important in considering the specificity of the different parts because of their potential commercial or ecological use in forest ecosystems.
\end{abstract}

\footnotetext{
Handling Editor: Reinhart Ceulemans

C. Herrero de Aza $(\bowtie) \cdot$ M. B. Turrión $\cdot$ V. Pando $\cdot$ F. Bravo

Sustainable Forest Management Institute (UVa-INIA),

ETS Ingenierías Agrarias, University of Valladolid,

Avda. Madrid 44,

34071 Palencia, Spain

e-mail: chdeaza@pvs.uva.es
}

Keywords Pinus nigra Pinus pinaster. Pinus sylvestris . Radial and axial Carbon concentration - Anatomical parts

\section{Introduction}

Wood production under sustainable forest management strategies has positive environmental effects since forests fix large amounts of carbon dioxide. Stem tree carbon (C) fixation can be calculated easily by using biomass equations or biomass expansion factors (BEFs) and multiplying each value by a generic $\mathrm{C}$ concentration of $50.0 \mathrm{cg} \mathrm{g}^{-1}$ dry matter, according to Kollmann (1959) and the Intergovernmental Panel on Climate Change (IPCC) recommendations (Penman et al. 2003). Although this concentration has been widely accepted, other reports support the view that the $\mathrm{C}$ concentration of wood varies depending on the species, stem anatomical parts, growth, site conditions, stand characteristics and management practices (Elias and Potvin 2003). Previous studies have shown that the concentration can vary from 48 to $54.4 \mathrm{cg}$ $\mathrm{g}^{-1} \mathrm{dm}$ in temperate pines (Matthews 1993). Lamlom and Savidge (2003) found that the heartwood of different softwood species from North America showed a C concentration between 47.2 and $55.2 \mathrm{cg} \mathrm{g}^{-1} \mathrm{dm}$. Differences could be expected because of the radial and vertical variation in wood characteristics. Anatomically, the stem is composed of heartwood, sapwood and bark, which show different properties and chemical compositions. Secondary compounds therefore tend to accumulate in heartwood, while storage products (starch), soluble sugars, amino-acids and mineral elements are removed from senescing sapwood rings (Meerts 2002).

In recent decades, a large amount of new data on mineral element concentrations in sapwood and heartwood anatom- 
ical parts has been published (Augusto et al. 2008). Studies to ascertain the chemical properties along the stem and in the different parts have also been carried out to attempt to improve yields in pulp industry (Barahona 2005). However, there is a lack of specific studies on the variation in $\mathrm{C}$ concentration within and along the stem. Improved knowledge of $\mathrm{C}$ concentration along the stem is relevant to adequate $\mathrm{C}$ quantification at tree and stand levels, and to the reduction of uncertainties in biomass $\mathrm{C}$ estimation (Zhang et al. 2009).

In this paper, C concentration patterns in heartwood, sapwood and bark were explored along the stem in three different species. Our specific objectives were: (1) to assess variation ranges and mean values of $\mathrm{C}$ concentration in heartwood, sapwood and bark; (2) to test whether this concentration was constant along the stem height; and (3) to test whether the heartwood/ sapwood/bark $\mathrm{C}$ concentration varied depending on the species considered.

\section{Materials and methods}

\subsection{Study area}

The study area is situated in northern Spain. This area represents a homogeneous transitional sector between the mountainous and crop areas, with small mountains and valleys. Altitude ranges from 800 to 1,000 ma.s.l. (Fig. 1). The climate is Mediterranean, with a long, cold winter and a warm, dry summer (a mean temperature of $10.7^{\circ} \mathrm{C}$ and mean annual rainfall of $630 \mathrm{~mm}$ ).

The present study is located in Pinus spp. plantations established mostly during the 1960s. These are young- and middle-aged plantations (around 30-60 years old) of Black pine (Pinus nigra), Maritime pine (Pinus pinaster) and Scots pine (Pinus sylvestris). Scattered patches of Heather (Erica spp.) and Rock roses (Cistus spp.) can also be found. The soils can be classified as Ultisols and Alfisols.

\subsection{Sampling and analytical method procedures}

Nine permanent plots $(30 \times 30 \mathrm{~m})$ were measured, covering different site qualities and densities to represent the whole study area (Table 1). They were located in middle-aged stands. In each plot, the diameter at breast height (dbh) and the total height of all trees were recorded. A total of 34 trees were sampled to obtain wood samples: 12 trees from $P$. pinaster, 12 from $P$. sylvestris and 10 from P. nigra were used (Table 2).

Trees were felled as close to the ground as possible in autumn 2004. Cross-sectional disks, $5 \mathrm{~cm}$ thick, were collected at several points along the stem. Disks were taken from each section, starting at stump height, then at heights of $0.3 \mathrm{~m}, 0.8 \mathrm{~m}$, breast height $(1.3 \mathrm{~m})$ and at $1 \mathrm{~m}$ intervals along the stem up to the end. To obtain the test material, the disks were divided into heartwood, sapwood and bark parts. The delimitations of the different parts were made by visual observation of the wood cross-section because the heartwood showed a distinctive brown color compared to the lighter-colored sapwood. Samples from the different parts and heights along the stem were extracted by a jig saw and dried. Each sample of dry wood (ca. $50 \mathrm{~g}$ ) was directly ground into $0.2 \mathrm{~mm}$ powder by two types of mills. Larger samples were first ground in an Ultra Centrifugal Mill $(10 \mathrm{~mm})$ and then a subsample was ground in a Mixed Mill, with a final fineness of about $5 \mu \mathrm{m}$. The $\mathrm{C}$ concentration [cg g ${ }^{-1}$ dry matter $\left.\left(\mathrm{cg} \mathrm{g}^{-1} \mathrm{dm}\right)\right]$ was analyzed using an automated $\mathrm{C} / \mathrm{N}$ analyzer (CHN-2000 LECO; analytical error: $\mathrm{C}: \pm 0.07 \%)$. A total of 1,006 samples was analyzed to determine $\mathrm{C}$ concentration. The number of samples taken from each stem depended directly on the height and the formation of heartwood. Consequently, for example, Pinus nigra trees sampled did not present enough heartwood area to get wood samples. Along the stem, from stump height up to a height of $6.3 \mathrm{~m}$, the average sapwood/heartwood ratio varied in the different species (Pinus nigra: 15.4-1.1; Pinus pinaster; 5.0-1.2; Pinus sylvestris: 8.6-0.6).

Bulk density $\left(\mathrm{g} \mathrm{cm}^{-3}\right)$ was calculated for the different parts, heights and species, as well as the ratio between
Fig. 1 Location and climatic diagram of the study area in Northern Spain. $T^{a}$ Mean annual temperature $\left({ }^{\circ} \mathrm{C}\right), P$ mean annual precipitation $(\mathrm{mm})$

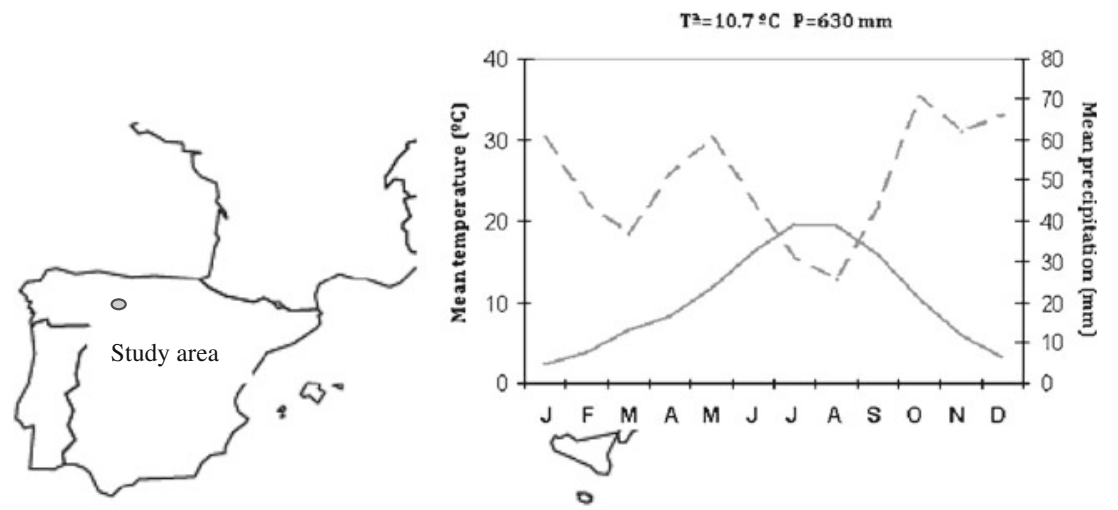


Table 1 Main plot characteristics. $X, Y$ UTM coordinates of the plots; $d$ mean dbh (diameter at breast height) of the plot; $Q M D$ quadratic mean diameter; Hdom dominant height; $N$ number of trees per hectare; $B A$ basal area of stand

\begin{tabular}{|c|c|c|c|c|c|c|c|c|}
\hline Plot & X Location & Y Location & $\mathrm{d}(\mathrm{cm})$ & QMD (cm) & Hdom (m) & $\mathrm{N}\left(\right.$ stem $\left.\mathrm{ha}^{-1}\right)$ & BA $\left(\mathrm{m}^{2} \mathrm{ha}^{-1}\right)$ & Trees sampled ${ }^{\mathrm{a}}$ \\
\hline \multicolumn{9}{|c|}{ Pinus nigra } \\
\hline Site 1 & 369688 & 4713892 & 16.3 & 16.7 & 11.1 & 1,833 & 40.0 & 4 \\
\hline Site 2 & 346814 & 4723449 & 19.3 & 19.7 & 7.5 & 689 & 21.0 & 2 \\
\hline Site 3 & 388565 & 4728054 & 19.1 & 19.5 & 14.4 & 1,367 & 40.8 & 4 \\
\hline \multicolumn{9}{|c|}{ Pinus pinaster } \\
\hline Site 4 & 384998 & 4712559 & 31.9 & 32.1 & 15.2 & 478 & 38.6 & 5 \\
\hline Site 5 & 390702 & 4704958 & 18.0 & 23.7 & 12.7 & 667 & 29.3 & 3 \\
\hline Site 6 & 392609 & 4708014 & 25.5 & 26.1 & 13.1 & 689 & 36.7 & 4 \\
\hline \multicolumn{9}{|c|}{ Pinus sylvestris } \\
\hline Site 7 & 347970 & 4728484 & 24.0 & 24.3 & 15.9 & 733 & 34.0 & 4 \\
\hline Site 8 & 372411 & 4715563 & 20.5 & 20.8 & 13.2 & 1,100 & 37.4 & 4 \\
\hline Site 9 & 352392 & 4724462 & 23.6 & 24.1 & 6.5 & 678 & 31.0 & 4 \\
\hline
\end{tabular}

${ }^{\text {a }}$ Trees harvested to carry out this study

oven-dry weight and fresh volume. Three different trees by species, whose diameter was close to the plot quadratic mean diameter, were chosen to estimate the average wood bulk density by parts and along the stem. Disks obtained, as in the previous case, were cut into smaller pieces to calculate dry weight and fresh volume. Disks from the different parts were oven-dried at $75 \pm 2^{\circ} \mathrm{C}$ to constant weight, and fresh volume was obtained using the water displacement method (measured to the nearest $0.001 \mathrm{~g}$; McDonald et al. 1995).

The stem $\mathrm{C}$ content by volume unit $\left(\mathrm{Mg} \mathrm{m}^{-3}\right)$ was calculated through $\mathrm{C}$ concentration and wood bulk density along the stem, and the total $\mathrm{C}$ mass $(\mathrm{Mg})$ was calculated by multiplying $\mathrm{C}$ content by volume unit and by the volume of this section (Fig. 2). The volume of the section was calculated as the volume that exists between two subsequent samples. In the case of bark components, C concentration was multiplied by the proportion of bark in the cross-section at the different heights. Stem wood volume $\left(\mathrm{V}, \mathrm{m}^{3}\right.$ tree $\left.^{-1}\right)$ and heartwood volume $\left(\mathrm{HV}, \mathrm{m}^{3}\right.$ tree $\left.^{-1}\right)$ were determined using Smalian's method (i.e., each portion considered a cone-trunk) for each intermediate section. Sapwood volume $\left(\mathrm{SV}, \mathrm{m}^{3}\right.$ tree $\left.^{-1}\right)$ and bark volume (BV, $\mathrm{m}^{3}$ tree $^{-1}$ ) were derived by the difference between those and the stem wood volume without bark. The total $\mathrm{C}$ mass $(\mathrm{Mg})$ was quantified in the different anatomical parts, heights and species. These variables allowed us to calculate a weighted mean $\mathrm{C}$ concentration by species (Bert and Danjon 2006) to exclude the effect of biomass allocation.

\subsection{Statistical methods}

Descriptive analyses of the $\mathrm{C}$ concentration at different heights and parts from the different species were carried out. A mixed model was fitted to assess the influence of the different factors such as anatomical part (with three levels: Heartwood, Sapwood and Bark) and species (with three levels: P. nigra, $P$. pinaster and $P$. sylvestris) along the stem on the $\mathrm{C}$ concentration. The following model was fitted (Eq. 1):

$$
\begin{aligned}
Y_{i j k}^{(l m)}= & \left(\alpha_{0}+\alpha_{i}^{(l)}\right)+\left(\beta_{o 1}+\beta_{i 1}^{(l)}\right) * h_{i j k}^{(l m)} \\
& +\left(\beta_{o 2}+\beta_{i 2}^{(l)}\right) *\left(h_{i j k}^{(l m)}\right)^{2}+\delta_{i j}+\varepsilon_{i j k}^{(l m)}
\end{aligned}
$$

where, $Y_{i j k}^{(l m)}=$ carbon concentration $\left(\mathrm{cg} \mathrm{g}^{-1} \mathrm{dm}\right)$ of tree $k$ in plot $j$ and of specie $i$ of anatomical part $l$ at cross sectional

\begin{tabular}{|c|c|c|c|c|c|c|c|c|c|c|c|c|c|c|c|c|c|}
\hline & \multirow[b]{2}{*}{$n$} & \multicolumn{4}{|l|}{$\mathrm{d}(\mathrm{cm})$} & \multicolumn{4}{|l|}{$\mathrm{h}(\mathrm{m})$} & \multicolumn{4}{|c|}{ hc (m) } & \multicolumn{4}{|c|}{ Age (years) } \\
\hline & & Mean & $\mathrm{SD}$ & Min & Max & Mean & $\mathrm{SD}$ & Min & Max & Mean & SD & Min & Max & Mean & SD & Min & $\operatorname{Max}$ \\
\hline Pinus nigra & 10 & 19.5 & 4.5 & 10.7 & 24.1 & 11.3 & 1.8 & 7.1 & 13.7 & 3.6 & 1.4 & 1.8 & 6.1 & 34 & 5 & 27 & 39 \\
\hline Pinus pinaster & 12 & 27.2 & 5.1 & 17.1 & 34.9 & 12.7 & 1.6 & 11.0 & 16.1 & 5.1 & 1.4 & 3.1 & 7.1 & 42 & 8 & 29 & 50 \\
\hline Pinus sylvestris & 12 & 21.0 & 3.9 & 13.4 & 26.5 & 13.4 & 2.0 & 8.6 & 15.7 & 6.7 & 2.3 & 4.5 & 11.2 & 42 & 6 & 36 & 53 \\
\hline
\end{tabular}

Table 2 Mean characteristics of harvested trees. $d$ dbh of the harvested tree; $h$ total height; $h c$ crown insertion height; Age age of harvested tree 
Fig. 2 Total carbon estimation by stem. Note: carbon $_{i j k}^{(l m)}$ is the total carbon content (in $\mathrm{Mg}$ ) of tree $k$ in plot $j$ and of specie $i$ of anatomical part $l$ at height $m, \mathrm{C}_{\mathrm{ijk}}$ is the carbon concentration (in $\mathrm{g} \mathrm{g}^{-1}$ ), $\rho_{i}^{(\mathrm{lm})}$ is the bulk density (in $\mathrm{g} \mathrm{cm}^{-3}$ ) of specie $i$ of anatomical part $l$ at height $m$ and $V o l_{i j k}^{(l m)}$ is the stem volume (in $\mathrm{m}^{3}$ ) of tree $k$ of plot $j$ and of specie $i$ of anatomical part $l$ at height $m$

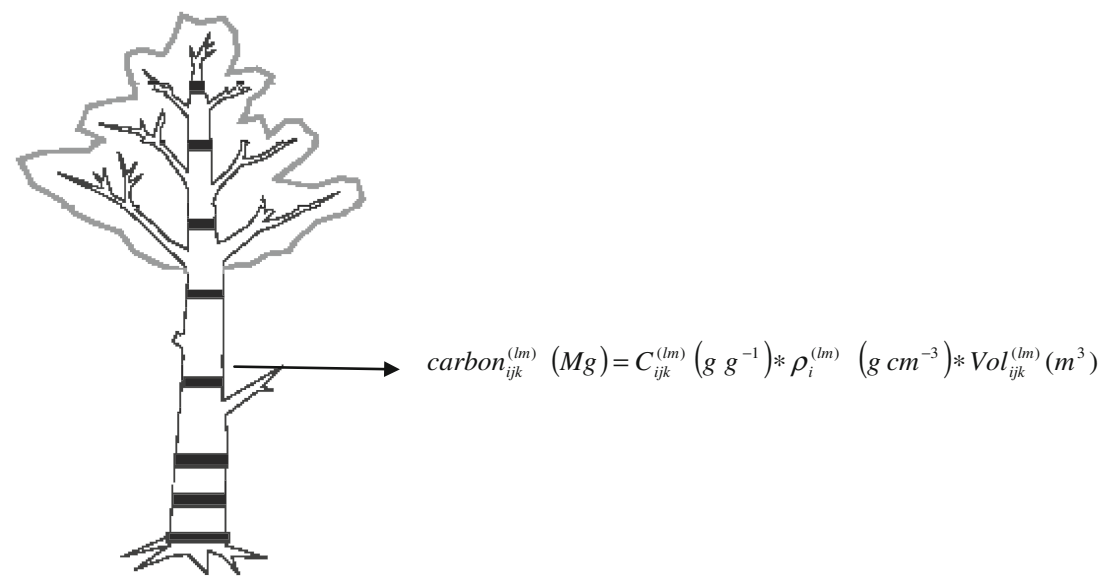

disk $m ; \alpha_{0}$ is the general intercept ; $\alpha_{i}^{(l)}$ is the effect of anatomical part $l$ on the intercept for specie $i ; \beta_{01}$ is the general linear effect of height on the carbon concentration; $\beta_{i 1}^{(l)}$ is the effect of anatomical part $l$ on the general linear coefficient of the height for specie $i$; $h_{i j k}^{(l m)}$ is the height (cm) to a simple power of tree $k$ in plot $j$ and of specie $i$ of anatomical part $l$ where the sample is extracted; $\beta_{02}$ is the general quadratic effect of height on the carbon concentration; $\beta_{i 2}^{(l)}$ is the effect of anatomical part $l$ on the general quadratic coefficient of the height for specie $i . ;\left(h_{i j k}^{(l m)}\right)^{2}$ is the height to the square of tree $k$ in plot $j$ and of specie $i$ of anatomical part $l$ where the sample is extracted; $\delta_{\mathrm{ij}}$ is the random effect of plot $j$ of species $i(\mathrm{j}=1,2,3)$ where $\delta_{i j} \rightarrow N\left(0, \sigma_{\delta}^{2}\right)$; and $\varepsilon_{i j k}^{(l m)}$ is the random error of part $l$ at cross sectional disk $m$ in tree $k$ in plot $j$ and in species $i$, where $\varepsilon_{i j k}^{(l m)} \rightarrow N_{51}(\overline{0}, \Sigma) . \Sigma$ is an un@AR(1) variance-covariance matrix (unstructured for anatomical parts and first-order autoregressive parameter for heights). With this variance structure, we consider the next three assumptions:

1. For every fixed height, we suppose that the variancecovariance matrix between anatomical parts is a general symmetrical $3 \times 3$ matrix, $A=\left(\begin{array}{ccc}\sigma_{1}^{2} & \sigma_{12} & \sigma_{13} \\ \sigma_{12} & \sigma_{2}^{2} & \sigma_{23} \\ \sigma_{13} & \sigma_{23} & \sigma_{3}^{2}\end{array}\right)$, with six variance parameters.

2. For every anatomical part $l$, we suppose that the variance-covariance matrix between heights is a firstorder autoregressive $17 \times 17$ matrix with the variance $\sigma_{l}^{2}$ for this part in the first diagonal, $\rho \sigma_{l}^{2}$ in the second diagonal, $\rho^{2} \sigma_{l}^{2}$ in the third diagonal and so on, up to $\rho^{16} \sigma_{l}^{2}$ in the last diagonal. Therefore, we have a new variance parameter: the correlation coefficient $\rho$ between consecutive heights.
3. The observations of different anatomical parts at different heights are independent. To estimate the eight variance parameters, we use the restricted maximum likelihood method (REML).

The adequacy of the model was analyzed by the simultaneous test of the equation parameters between actual and predicted values (Eq. 2). This test was used to ascertain if the model was biased or not. The simultaneous F-test of $\mathrm{c}_{10}=0$ and $\mathrm{c}_{11}=1$ was a good, intuitive and reasonable test. Presumably, the intuition underlying this test was that if the model was a good one, the regression between actual and predicted values should be a $45^{\circ}$ line and demonstrate that the model was unbiased (Huang et al. 2003).

actual $=c_{10}+c_{11}$ predicted

where actual was the value of $\mathrm{C}$ concentration and predicted was the value obtained by using the model, while $\mathrm{c}_{10}$ and $\mathrm{c}_{11}$ were the parameters to be adjusted. Finally, the efficiency of the model was tested by the calculation of the pseudo-determination coefficient (pseudo $R^{2}$ ) of the regression between actual and predicted.

Least square means (lsmeans) of the different parts and species were considered significant at $P<0.05$ at different heights. Differences among parts in the different species and differences among species in the different parts were analyzed at a height equal to $1.3 \mathrm{~m}$. This height was chosen because it would be a reference point in forest inventories. However, the tendency of $\mathrm{C}$ concentration along the stem was also analyzed by individual contrasts of the coefficients. This analysis allowed us to know species and anatomical part patterns. The model was fitted with PROC MIXED SAS software (SAS Institute 2010). The analysis of the R-Student residuals was also carried out by plots. PROC UNIVARIATE (SAS Institute 2010) was used to check the normality, independence and homocedasticity of the R-Student residuals. 


\section{Results}

The carbon concentration in heartwood ranged from 44.0 to $58.9 \mathrm{cg} \mathrm{g}^{-1} \mathrm{dm}$ in P. pinaster, which was similar to the value in P. sylvestris (from 44.2 to $59.7 \mathrm{cg} \mathrm{g}^{-1} \mathrm{dm}$ ). In sapwood, while the maximum values obtained were similar among species (around $48 \mathrm{cg} \mathrm{g}^{-1} \mathrm{dm}$ ), the minimal values were less than $43 \mathrm{cg} \mathrm{g}^{-1} \mathrm{dm}$ in $P$. pinaster, less than 41 in $P$. nigra and less than $40 \mathrm{cg} \mathrm{g}^{-1} \mathrm{dm}$ in $P$. sylvestris. The carbon concentration in bark varied greatly between the different species. In the case of $P$. nigra, values ranged from $41.5 \mathrm{cg} \mathrm{g}^{-1} \mathrm{dm}$ to $54.6 \mathrm{cg} \mathrm{g}^{-1} \mathrm{dm}$, from $46.6 \mathrm{cg} \mathrm{g}^{-1} \mathrm{dm}$ to $51.6 \mathrm{cg} \mathrm{g}^{-1} \mathrm{dm}$ in P. pinaster and from $41.8 \mathrm{cg} \mathrm{g}^{-1} \mathrm{dm}$ to $59.8 \mathrm{cg} \mathrm{g}^{-1} \mathrm{dm}$ in P. sylvestris.

The mixed model showed that the height at simple and square powers, the double interaction between species and anatomical parts, and the third interaction among species, anatomical parts and heights were highly significant at $\alpha<0.05$ (Table 3). The $\mathrm{C}$ concentration at each height thus depended on the species and the anatomical part considered. The regression line between actual and predicted values, which analyzed the adequacy of the model, showed that the independent term is not significantly different from zero and the slope is not significantly different from one. The simultaneous test of the parameters of the equation between real and predicted values $(\operatorname{Pr}>\mathrm{F}=$ 0.7326 ) indicated that there was no bias in the carbon model. The pseudo $R^{2}$ statistics of the regression between actual and predicted values (pseudo $R^{2}=0.4891$ ) showed a good performance of the fit.

Significant differences between species were found (Table 4) in the $\mathrm{C}$ concentration of the different anatomical parts at a height of $1.3 \mathrm{~m}$. While in P. nigra and P. sylvestris, significant differences were found in $\mathrm{C}$ concentration in heartwood, sapwood and bark tissues, heartwood and bark in $P$. pinaster did not show this characteristic. In comparison with the heartwood component, the carbon concentration of the bark was higher in $P$. pinaster and lower in $P$. sylvestris.

Table 4 also presents the significant differences between anatomical parts in the different species at a height of $1.3 \mathrm{~m}$. In heartwood, the $\mathrm{C}$ concentration was different in two species considered (P. pinaster and P. sylvestris). On the other hand, in sapwood, the $\mathrm{C}$ concentration obtained in $P$. nigra was different from that of $P$. sylvestris, but both were similar to the $\mathrm{C}$ concentration of $P$. pinaster. Finally, in bark, $P$. sylvestris was different with respect to the other two Pinus species, but there were no significant differences between P. nigra and P. pinaster.

Carbon concentration $\mathrm{C}\left(\mathrm{cg} \mathrm{g}^{-1} \mathrm{dm}\right)$ against height $\mathrm{h}(\mathrm{m})$ showed different patterns in the three species considered in the three anatomical parts studied (Table 5, Fig. 3). In heartwood, the $\mathrm{C}$ concentration decreased with increased stem height in two species (P. pinaster and P. sylvestris). On the other hand, the $\mathrm{C}$ concentration in sapwood increased along the stem, although in P. pinaster a slight decrease was found near the base of the stem. Finally, the $\mathrm{C}$ concentration estimated in bark depended on the species considered. While a decreasing trend was found in $P$. pinaster, the values were higher at the base and top of the stem and at their lowest in the middle in P. nigra and P. sylvestris.

Comparing species, in P. nigra, there were significant differences between sapwood and bark parts at heights of less than $4.3 \mathrm{~m}$. In P. pinaster, sapwood was different from heartwood and bark parts up to 2.3 and $11.3 \mathrm{~m}$, respectively, while there were no significant differences between bark and heartwood parts along the stem. Finally, in P. sylvestris, there were significant differences among the three parts up to a height of $4.3 \mathrm{~m}$, the heartwood being completely different along the stem with respect the other two parts.

To provide an average $\mathrm{C}$ concentration for the species studied, considering the different anatomical parts and the variation along the stem, a weighted mean $\mathrm{C}$ concentration was calculated for each species. These concentrations were $46.4 \pm 1.7 \mathrm{cg} \mathrm{g}^{-1}$ (P. nigra), $46.8 \pm 1.6$ (P. pinaster) and $45.9 \pm 1.5 \mathrm{cg} \mathrm{g}^{-1}$ (P. sylvestris).

The study results reveal that the mean sapwood wood bulk density decreased when stem height increased, in all three species considered (Fig. 4). At stump level, the bulk density had the maximum values (above $0.4 \mathrm{gcm}^{-3}$ in Pinus nigra and Pinus pinaster). At $1.3 \mathrm{~m}$, the values were close to $0.35 \mathrm{~g} \mathrm{~cm}^{-3}$ in the three species. However, at heights of more than $4 \mathrm{~m}$, the bulk density fell to below $0.3 \mathrm{gcm}^{-3}$ because of the fresh volume in a small dry weight value.

The $\mathrm{C}$ content by volume unit $\left(\mathrm{Mg} \mathrm{m}^{-3}\right)$ by species and parts is shown in Fig. 5. Sapwood values obtained in the three species of Pinus were very similar. In bark, the trend found in Pinus sylvestris showed the smallest values along the stem, while the pattern was the opposite in heartwood.

\section{Discussion}

Our study focused on the different $\mathrm{C}$ concentrations in the different anatomical parts along the stem in three Pinus species. The differences in $\mathrm{C}$ concentration found in heartwood, sapwood and bark could be due to the differences in physical and chemical properties in these tissues. The physical differences were due to the lack of physiological activity in heartwood and to the structural and chemical changes that occur during the formation of heartwood. Heartwood is a biologically dead anatomical part, lacking biologically living cells (Climent et al. 1998). During heartwood formation, cells change their dimensions and functions, chemical transformations occur by develop- 
Table 3 Type 3 tests for fixed effects in the mixed model of carbon concentration. NumDF, $D e n D F$ Numerator and denominator degrees of freedom, respectively; F-Value value of the Fstatistic; $P r>F P$-value associated with the previous F-statistic

\begin{tabular}{lllll}
\hline Effect & NumDF & DenDF & F-Value & Pr $>$ F \\
\hline Height & 1 & 968 & 17.88 & $<.0001$ \\
Height $^{2}$ & 1 & 968 & 6.37 & 0.0118 \\
Species $\times$ anatomical part & 7 & 968 & 29.96 & $<.0001$ \\
Height $\times$ Species $\times$ Anatomical part & 7 & 968 & 6.08 & $<.0001$ \\
Height $^{2} \times$ Species $\times$ Anatomical part & 7 & 968 & 3.34 & 0.0016 \\
\hline
\end{tabular}

ment of tyloses in the vessels of many species (Hillis 1987), and the biosynthesis of non-structural compounds leads to an important accumulation of extractives. Differences among tissues have been found by previous researchers (Augusto et al. 2008; Bert and Danjon 2006; Fukatsu et al. 2008) and higher concentrations of extractives (resins, tannins, etc.) in heartwood than in sapwood have been shown by previous researchers (Campbell et al. 1990; Climent et al. 1998; Bergstrom 2003; Fukatsu et al. 2008). As well as this, higher levels of extractives, lignin and tannins in bark in comparison to the other anatomical parts were found by Bert and Danjon (2006) in 50-year-old plantations of Pinus pinaster in France. This difference could be due to phenolic constituents, with a $\mathrm{C}$ composition that could range from 40 to $88 \mathrm{cg} \mathrm{g}^{-1} \mathrm{dm}$, although most $\mathrm{C}$ concentrations are higher than $60 \mathrm{cg} \mathrm{g}^{-1} \mathrm{dm}$. All these components increase the $\mathrm{C}$ concentration in heartwood and bark areas. In addition, nutrients (such as nitrogen, phosphorous and others) are translocated to youngergrowing tissues. This can also play a role in changing the $\mathrm{C}$ concentration in mature tissues.

Our results show that $\mathrm{C}$ concentration depends on the species studied. Among pine species, $P$. pinaster and $P$. sylvestris also show a higher $\mathrm{C}$ concentration in heartwood

Table 4 Level of significance means of $\mathrm{C}$ concentration, standard error and the lower (Lci) and upper (Uci) confidence interval limits, in $\mathrm{cg} \mathrm{g}^{-1}$ dry matter $(\mathrm{dm})$, for the different species and anatomical parts at $1.30 \mathrm{~m}$ height. For each species, means of anatomical parts without than in sapwood at a height of $1.30 \mathrm{~m}$ (Table 4). This may also be due to the presence of resinous components. Other studies have shown similar results (Elias and Potvin 2003; Lamlom and Savidge 2003; Tamura et al. 2006). For example, in Pinus canariensis, Climent et al. (1998) found that resinification starts in latewood tracheids, observed at the heartwood boundary, especially in those sections where heartwood formation is at an early stage. However, a limitation of our study was its strong dependence on the trees available for study in obtaining the results found for heartwood C presence; heartwood formation had just started in $P$. sylvestris and $P$. pinaster, in contrast to $P$. nigra. The most common age at which transformation from heartwood to sapwood occurs is reported to be 14-18 years (Hillis 1987). However, it could be 60-100 years in beech (Fagus sylvatica) or European ash (Fraxinus excelsior), as reported by Dadswell and Hillis (1962). In addition, the sapwood/heartwood ratio varies with many factors, including species, age, climate, growth rate, foliage area, site quality and tree vitality, and has been the subject of several reviews (Yang and Hazenberg 1991). The pine plantations we studied were from 30 to 60 years old. By increasing the sample size with older trees, our findings could be improved. any common lower-case letters are different at the 0.05 level of significance. For each anatomical part, means of species without any common upper-case letters are different at the 0.05 level of significance

\begin{tabular}{|c|c|c|c|c|c|c|}
\hline Species & Anatomical part & $n$ & $\begin{array}{l}\text { Mean carbon } \\
\text { concentration } \\
\left(\mathrm{cg} \mathrm{g}^{-1} \mathrm{dm}\right)\end{array}$ & Standard error & $\mathrm{Lc}_{\mathrm{i}}$ & $\mathrm{Uc}_{\mathrm{i}}$ \\
\hline \multicolumn{7}{|c|}{ Pinus nigra } \\
\hline & Sapwood & 112 & 46.5 a $\mathrm{A}$ & 0.4 & 45.8 & 47.3 \\
\hline & Bark & 106 & $49.9 \mathrm{~b} \mathrm{~A}$ & 0.5 & 48.9 & 50.9 \\
\hline \multicolumn{7}{|c|}{ Pinus pinaster } \\
\hline & Heartwood & 87 & $49.5 \mathrm{~b} \mathrm{~A}$ & 0.9 & 47.6 & 51.3 \\
\hline & Sapwood & 156 & 45.8 a $\mathrm{AB}$ & 0.4 & 45.1 & 46.5 \\
\hline & Bark & 137 & $50.1 \mathrm{~b} \mathrm{~A}$ & 0.5 & 49.1 & 51.0 \\
\hline \multicolumn{7}{|c|}{ Pinus sylvestris } \\
\hline & Heartwood & 76 & $52.3 \mathrm{c} \mathrm{B}$ & 1.0 & 50.4 & 54.2 \\
\hline & Sapwood & 166 & 45.3 a $\mathrm{B}$ & 0.4 & 44.5 & 46.0 \\
\hline & Bark & 166 & $48.5 \mathrm{~b} \mathrm{~B}$ & 0.5 & 47.6 & 49.4 \\
\hline
\end{tabular}


Table 5 Linear components of the heartwood, sapwood and bark mixed models for the different Pinus species. $\alpha_{0}$, $\beta_{1}$ and $\beta_{2}$ are the parameters of the models for the different species and anatomical parts; $S E$ standard error

\begin{tabular}{llllllll}
\hline & & $\alpha_{0}$ & SE & $\beta_{1}$ & se & $\beta_{2}$ & SE \\
\hline Pinus nigra & sapwood & 464 & 0.4548 & 0.1379 & 0.1546 & -0.00328 & 0.01461 \\
& bark & 508 & 0.6137 & -0.7358 & 0.2413 & 0.05157 & 0.02336 \\
Pinus pinaster & heartwood & 514 & 11.065 & -16.999 & 0.6082 & 0.1630 & 0.07520 \\
& sapwood & 459 & 0.4163 & -0.08462 & 0.1215 & 0.01464 & 0.01030 \\
& bark & 504 & 0.5642 & -0.2536 & 0.1876 & 0.01115 & 0.01591 \\
Pinus sylvestris & heartwood & 530 & 11.708 & -0.5075 & 0.6719 & -0.00353 & 0.09193 \\
& sapwood & 453 & 0.4160 & -0.02049 & 0.1149 & 0.01011 & 0.008960 \\
& bark & 498 & 0.5449 & -10.436 & 0.1702 & 0.07004 & 0.01325 \\
\hline
\end{tabular}

Differences in heartwood, sapwood and bark C concentration were found along the stem with different patterns. Vertical variations were found in previous works (Bert and Danjon 2006; Campbell et al. 1990). Our bark variations agree with those obtained in P. pinaster by Bert and Danjon (2006). Our results showed a trend for increasing C concentration along the stem in sapwood and decreasing concentration in heartwood. The results for the heartwood could be due to the fact that older cross-sections had larger heartwood areas and greater $\mathrm{C}$ concentrations than younger sections, perhaps because of the higher amount of extractives and lignin accumulated in older parts. This pattern was found by Campbell et al. (1990) in P. contorta. However, in sapwood tissue, C concentration increased as stem height increased. Younger parts of sapwood tissue showed more $\mathrm{C}$ than older parts. Higher concentrations of nutrients have been found in younger trees than in mature trees (Augusto et al. 2008). This could be due to the greater cell activity near the crown. Finally, the triple interaction showed significant differences among species and anatomical parts along the stem. The different composition of the anatomical parts and the specific concentrations of lignin, resins and extractives could affect structural differences at different heights. The vertical gradients in $\mathrm{C}$ concentration
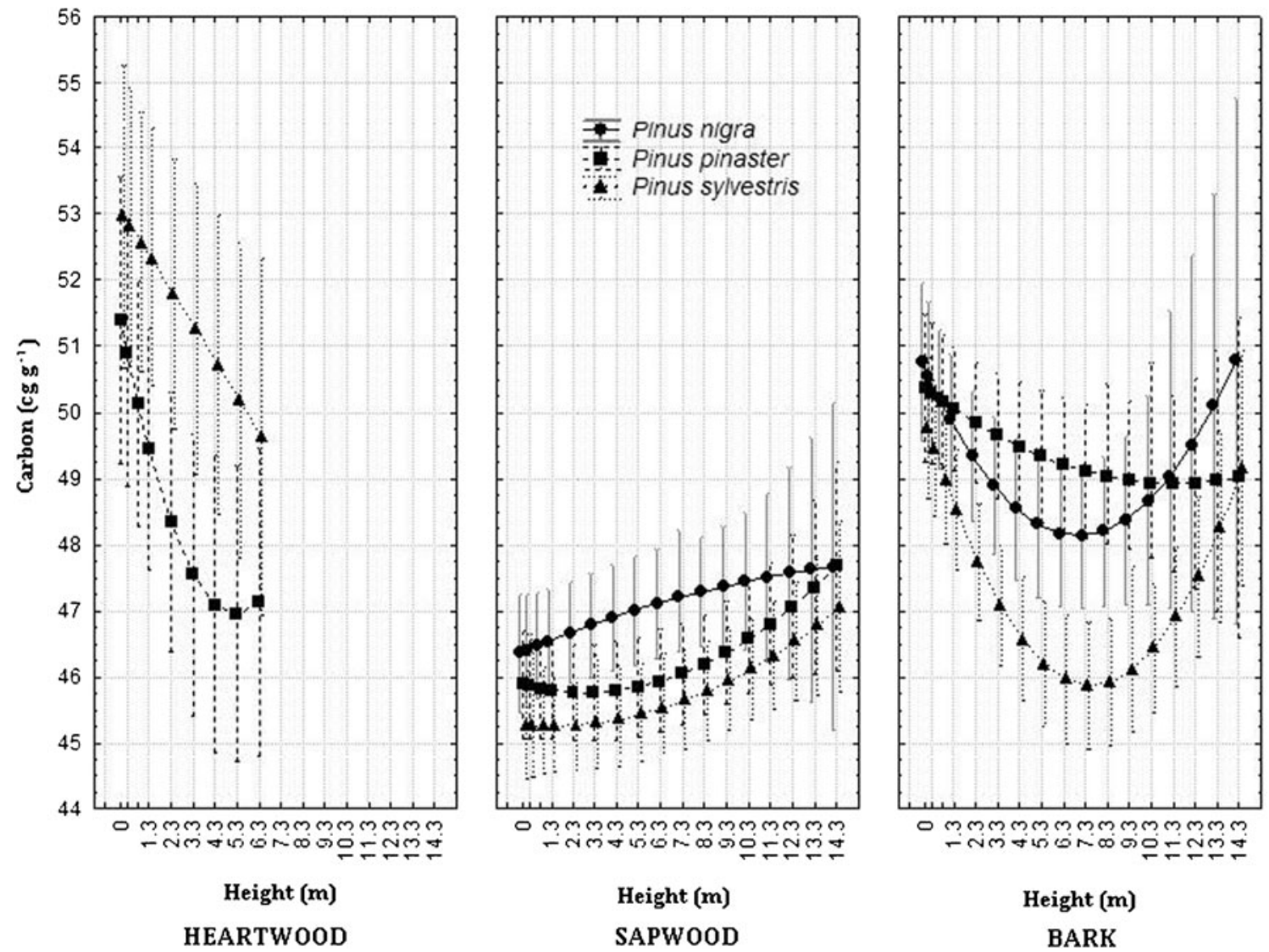

Fig. 3 Carbon content $\left(\mathrm{cg} \mathrm{g}^{-1} \mathrm{dm}\right)$ along stem height $[\mathrm{h}(\mathrm{m})]$ in the different species and anatomical parts and their confidence interval limits 
Bulk density $\left(\mathrm{g} \mathrm{cm}^{-3}\right)$

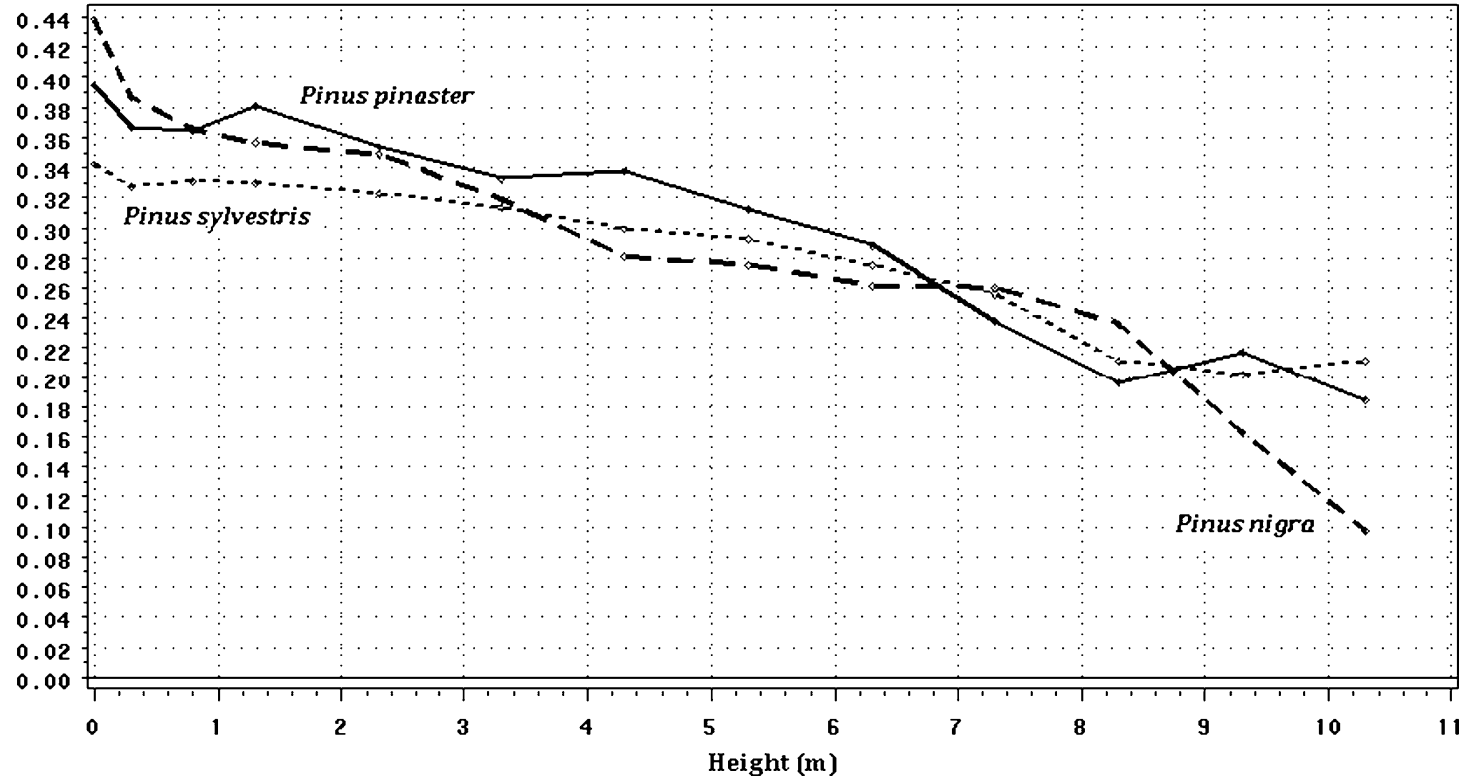

Fig. 4 Sapwood bulk density along the stem height by species

could result from variations of these factors according to stem height. Previous studies like that of Barahona (2005) showed significant differences in cellulose content at different heights, without a unique trend. However, patterns found by Bert and Danjon (2006) were more similar to those found in this study.

Although prior studies suggest that wood bulk density is higher when stem height increases (Barahona 2005), our

\section{$\mathrm{C}\left(\mathrm{Mg} \mathrm{m}^{-3}\right)$}

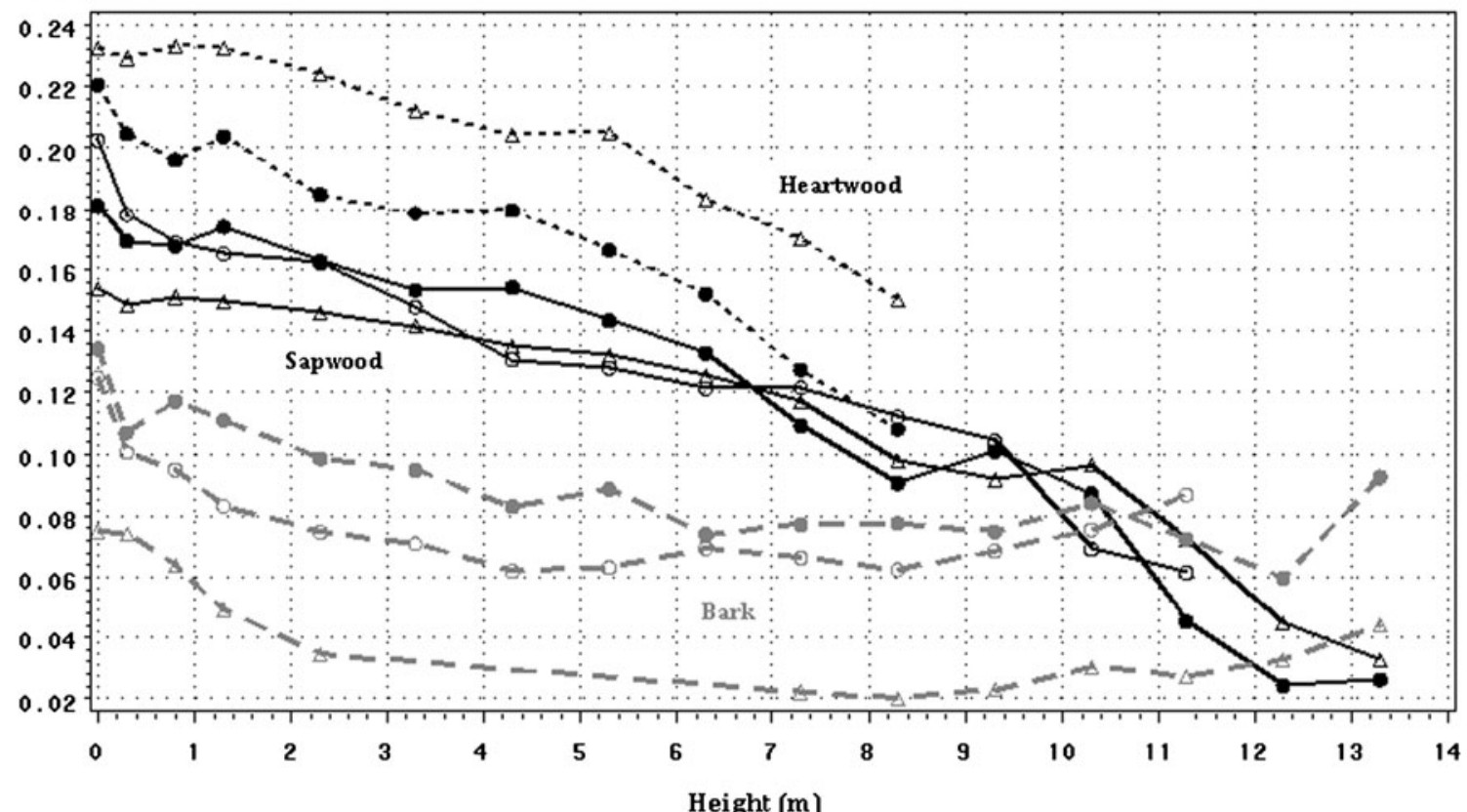

Pinus nigra Pinus pinaster Pinus sylvestris
Heartwood Sapwood Bark

\begin{tabular}{|c|c|}
\hline & $\theta \theta$ \\
\hline$\cdots$ & \\
\hline
\end{tabular}

Fig. 5 Carbon content by volume unit $\left(\mathrm{Mg} \mathrm{m}^{-3}\right)$ by anatomical parts in the species studied 
findings showed substantial variation in the species studied, with lower wood bulk density in the top of the stem. Higher values were found in heartwood bulk density than in sapwood bulk density. This is similar to the findings of Nogueira et al. (2008). Previous research points out that heartwood is reputed to be heavier, stronger and more resistant to decay than sapwood. Because of wood bulk density values, $\mathrm{C}$ content by volume unit was also higher in heartwood than in sapwood in our study. Consequently, at the same relative height, for each cubic meter, the $\mathrm{C}$ content in sapwood was lower than in heartwood. This agrees with other reports indicating that species with higher bulk density values, although they have lower $\mathrm{C}$ content per unit mass, nevertheless contain more $\mathrm{C}$ per unit volume (Lamlom and Savidge 2003). However, wood demands and $\mathrm{C}$ fixation must be balanced in the different forest compositions, because the heartwood of some species is of value for the wood industry (for example, Pinus canariensis) or the winery industry (Quercus spp.). In contrast, in other industries, heartwood is not so desirable because resins and other components hinder sawmill work.

Forest growth models or inventory data can be combined with tree biomass functions and $\mathrm{C}$ concentration data to estimate $\mathrm{C}$ stocks in tree biomass. Some authors consider that the use of $50.0 \mathrm{cg} \mathrm{g}^{-1} \mathrm{dm}$ could introduce over- or underestimates of $\mathrm{C}$ biomass into such calculations (Bert and Danjon 2006; Janssens et al. 1999), indicating the need to sample tree components in each stand for $\mathrm{C}$, mineral or mass studies. In this respect, in the current context of the Carbon Market, our detailed approach to determining $\mathrm{C}$ tree content could make a significant difference to global Carbon Credit transactions. This would be more important if the price of carbon credits rose above the current level. In our study, the weighted $\mathrm{C}$ obtained is similar in the three Pinus species, and smaller than $50 \mathrm{cg} \mathrm{g}^{-1} \mathrm{dm}$, the generic $C$ concentration widely promulgated. Janssens et al. (1999) obtained a mean value of $48.9 \mathrm{cg} \mathrm{g}^{-1} \mathrm{dm}$ in Pinus sylvestris, while Bert and Danjon (2006) and Zhang et al. (2009) found values less than $54 \mathrm{cg} \mathrm{g}^{-1} \mathrm{dm}$ in Pinus pinaster and Pinus koraiensis, respectively.

The IPCC suggests using species-specific C-concentration values when they are available. In this respect, our results are relevant because they provide detailed data for three species used extensively in reforestation projects.

Operational forestry needs accurate $\mathrm{C}$ estimation to establish sustainable forest management alternatives that increase forest carbon sinks. This study expands our knowledge of $\mathrm{C}$ in biomass by considering different values at different heights and anatomical parts, instead of taking a single value as is the current practice.
Further research on up-scaling, including result aggregation, will benefit the application of our findings in different stand types (structure, size or distribution).

Acknowledgments We express our gratitude to Francisco Lafuente for providing help with data support, methods and interpretation of the results. This study has been made possible through research under the FORSEE project-INTERREG III B program financed by the European Union and through the University of Valladolid grant program.

\section{References}

Augusto L, Meredieu C, Bert D, Trichet P, Porté A, Bosc A, Lagane F, Loustau D, Pellerin S, Danjon F, Ranger J, Gelpe J (2008) Improving models of forest nutrient export with equations that predict the nutrient concentration of tree compartments. Ann For Sci 65:808-822

Barahona GL (2005) Variación de la composición química en albura, duramen y altura de madera pulpable de Eucalyptus globulus proveniente de monte alto y monte bajo. Departamento de la Ingeniería de la Madera, Austral University of Chile, Valdivia, Chile, MSc thesis

Bergstrom B (2003) Chemical and structural changes during heartwood formation in Pinus sylvestris. Forestry 76:45-53

Bert D, Danjon F (2006) Carbon concentration variations in the roots, stem and crown of mature Pinus pinaster (Ait.). For Ecol Manag 222:279-295

Campbell AG, Kim WJ, Koch P (1990) Chemical variation in lodgepole pine with sapwood/heartwood, stem height, and variety. Wood Fiber Sci 22:22-30

Climent JA, Gil L, Pardos JA (1998) Xylem anatomical traits related to resinous heartwood formation in Pinus canariensis Sm. Trees 12:139-145

Dadswell HE, Hillins WE (1962) Wood. In: Hillis WE (ed) Wood extractives and their significance to pulp and paper industries. Academic, New York, pp 3-55

Elias M, Potvin C (2003) Assessing inter- and intra-specific variation in trunk carbon concentration for 32 neotropical tree species. Can J For Res 33:1039-1045

Fukatsu E, Fukuda Y, Takahashi M, Nakada R (2008) Clonal variation of carbon content in wood of Larix kaempferi (Japanese larch). J Wood Sci 54:247-251

Hillis WE (1987) Heartwood and tree exudates. Springer, Berlin

Huang S, Yang Y, Wang Y (2003) A critical look at procedures for validating growth and yield models. In: Amaro A, Reed D, Soares P (eds) Modelling Forest Systems. CABI, Wallingford, pp 271-293

Janssens IA, Sampson DA, Cermark J, Meiresonne L, Riguzzi F, Overloop S, Ceulema R (1999) Above and belowground phytomass and carbon storage in a Belgian Scots pine stand. Ann For Sci 56:81-90

Kollmann F (1959) Tecnología de la madera y sus aplicaciones. IFIE, Madrid

Lamlom SH, Savidge RA (2003) A reassessment of carbon content in wood: variation within and between 41 North American species. Biomass Bioenerg 25:381-388

Matthews RW (1993) The carbon content of trees. Technical Paper 4, Forestry Commission, Edinburgh

McDonald SS, Williamson GB, Wiemann MC (1995) Wood specific gravity and anatomy in Heliocarpus appendiculatus (Tiliaceae). Am J Bot 82:855-861 
Meerts P (2002) Mineral nutrient concentrations in sapwood and heartwood: a literature review. Ann For Sci 59:713-722

Nogueira EM, Fearnside PM, Nelson BW (2008) Normalization of wood density in biomass estimates of Amazon forests. For Ecol Manag 256:990-996

Penman J, Gytarsky M, Hiraishi T, Krug T, Kruger D, Pipatti R, Buendia L, Miwa K, Ngara T, Tanabe K, Wagner F (2003) Good practice guidance for land use, land-use change and forestry. IPCC/IGES, Hayama, Japan. Available at: http://www.ipcc-nggip. iges.or.jp/public/gpglulucf/gpglulucf contents

Sas Institute Inc. 2010 SAS/STATTM User's Guide, Relase 9.1. Cary, NC
Tamura A, Kurinobu S, Fukatsu E, Iizuka K (2006) An investigation on the allocation of selection weight on growth and wood basic density to maximize carbon storage in the stem of Sugi (Cryptomeria japonica D. Don) (in Japanese). J Jpn For Soc 88:15-20

Yang KC, Hazenberg G (1991) Sapwood and heartwood width relationship to tree age in Pinus banksiana. Can J For Res 21:521-525

Zhang Q, Wang C, Wang X, Quan X (2009) Carbon concentration variability of 10 Chinese temperate tree species. For Ecol Manag 258:722-727 